EMBRYARIDDLE
Aeronautical University

SCHOLARLY COMMONS
Journal of Aviation/Aerospace

Education \& Research

Volume 29

Number 3 JAAER 2020

Article 3

2020

\title{
What Type of Collegiate Pilot is Likely to Experience Imposter Phenomenon?
}

\author{
Rian Mehta \\ Florida Institute of Technology, rianmehta91@gmail.com \\ Stephen Rice \\ Embry-Riddle Aeronautical University \\ Tianhua Li \\ Florida Institute of Technology \\ Sadie Cooke \\ Embry-Riddle Aeronautical University \\ Ryan Lange \\ Embry-Riddle Aeronautical University
}

See next page for additional authors

Follow this and additional works at: https://commons.erau.edu/jaaer

Part of the Higher Education Commons, Human Factors Psychology Commons, and the Social Statistics Commons

\section{Scholarly Commons Citation}

Mehta, R., Rice, S., Li, T., Cooke, S., Lange, R., Black, M., Smith, C., Milner, M., Winter, S. R., Ragbir, N., \& Vaughn, A. (2020). What Type of Collegiate Pilot is Likely to Experience Imposter Phenomenon?. Journal of Aviation/Aerospace Education \& Research, 29(3). https://doi.org/10.15394/jaaer.2020.1857

This Article is brought to you for free and open access by the Journals at Scholarly Commons. It has been accepted for inclusion in Journal of Aviation/Aerospace Education \& Research by an authorized administrator of Scholarly Commons. For more information, please contact commons@erau.edu. 


\section{What Type of Collegiate Pilot is Likely to Experience Imposter Phenomenon?}

\section{Author(s)}

Rian Mehta, Stephen Rice, Tianhua Li, Sadie Cooke, Ryan Lange, Morgan Black, Cynthia Smith, Mattie Milner, Scott R. Winter, Nadine Ragbir, and Austin Vaughn 


\section{Introduction}

\section{Imposter Phenomenon}

Imposter (or Impostor) Syndrome (IS) is also known as the Imposter Phenomenon (IP), fraud syndrome, perceived fraudulence, or imposter experience (Bravata et al., 2019). IP has not been well researched within the aviation industry. The purpose of this study is to identify the factors that influence the prevalence of IP in collegiate pilots in training. This concept was originally introduced by Clance and Imes (1978), where it was named the Impostor Phenomenon (IP). The IP, in general, refers to internal self-doubt feelings, which are especially common among (a) high-achieving people, (b) members of minority groups, and (c) students (Mullangi \& Jagsi, 2019; Nimmo, 2019; Sherman, 2013). People who suffer from IP have propensities to doubt their external achievements and attribute them to external causes (e.g., luck, and support from others) or temporary internal quality (e.g., efforts) instead of permanently internal features (e.g., skill, capacity, competency). There is a fear of being unmasked as an imposter and losing credibility in the future (Bothello \& Roulet, 2019; Clance \& Imes, 1978; Hawley, 2019; Kolligian \& Sternberg, 1991; Nimmo, 2019; Sakulku \& Alexander, 2011).

The IP is not merely a negative feeling but can also lead to several issues. There are two major categories of outcomes, which are efforts and abandonments. Those who suffer from IP may mistakenly perceive that they are being compared to others, which makes them want to surpass their imaginary competitors and meet expectations of others (Hawley, 2019; Nimmo, 2019; Sherman, 2013). They assume that if their competitors perform at a level superior to them, they would be unmasked as frauds and feel ashamed and embarrassed. They often worry about being fired or blamed for pretending (Hawley, 2019). After experiencing these difficulties, victims of IP may suffer from depressive disorders, social anxiety, burnout, or high levels of self- 
consciousness (Kolligian \& Sternberg, 1991; Mullangi \& Jagsi, 2019; Sherman, 2013). Furthermore, it is also probable that IP sufferers lose confidence, which leads to lower performance and not meeting others' expectations. This in turn makes them become less confident, which creates a vicious cycle (Hawley, 2019). Consequently, this could lead to feelings of self-abandonment, causing them to transfer themselves to other industries or even generate self-handicapping attempts. The safety implications of depressive behaviors in aviation cannot be overstated. The lives of many individuals could be at risk, thereby warranting the need to study this phenomenon within the aviation industry further.

\section{Imposter Phenomenon in the Aviation Industry}

Although there is no research on the IP in aviation, this issue has been identified in many other industries. IP is frequent among three categories of individuals, including students, highachievement receivers, and minorities by gender, age, or race (Brauer \& Proyer, 2017; Caselman, Self, \& Self, 2006; Castro, Jones, \& Mirsalimi, 2004; Chayer \& Bouffard, 2010). It is prevalent among nurse and physician students and even practitioners (Villwock, Sobin, Koester, \& Harris, 2016). Research shows that a large portion of medical students and clinicians experience depression and anxiety as compared to other demographics (Mullangi \& Jagsi, 2019).

Moreover, high-achieving persons and minority members, such as women, young adults, and African Americans are frequent victims. For example, the IP was initially discovered by Clance and Imes (1978) because they concluded that high-achieving women did not possess an inherent sense of success. Similarly, Sherman (2013) stated that female leaders commonly did not believe they deserved their externally demonstrated successes; in this case, they wanted to work hard to prove their competency. 
This gap in the published literature regarding aviation should be addressed since there is reason to believe that aviators suffering from IP may also suffer from performance deficits that could impact safety.

Pilots demographics. According to 2018 U.S. airmen demographics data (Federal Aviation Administration [FAA], 2019), approximately one-fifth of U.S.-registered pilots were between 20 and 29 years old, and $7 \%$ within the whole age range $(46,463)$ were female pilots. The number of hired female pilots has been increasing by about 3,000 each decade since 1970 (Goyer, 2020). It is also reported by Data USA (2018) that in the United States, Caucasian pilots were more than $70 \%$ of the population. It can be implicated based on this data that female pilots and non-Caucasian pilots are minority members. This could be a first indication of demographics to research that may experience IP. The National Transportation Safety Board (NTSB) reported that male pilots hold higher accident rates than female pilots, but female pilots tend to doubt themselves due to contradiction with the overall social expectations and the small allocation of female pilots (Clance \& Imes, 1978; Mullangi \& Jagsi, 2019; Vail \& Ekman, 1986). Although young pilots are not a minority, they make a considerable portion of all pilots. Due to the typical age of a collegiate pilot in training being fairly young, age was included as a factor analyzed as it is important to see if it plays a role in self-assessment, such as IP, and if this phenomenon is more prevalent in younger participants.

Other than the public demographic information above, some other factors may define minorities as well, which include education levels, school types, and flight hours. For example, if most pilots obtained bachelor's or higher degrees, pilots with high school diplomas may consider themselves unqualified as pilots. Similarly, a person who received the training from a 14 CFR Part 61 flight school or has relatively fewer flight hours may perceive themselves to be less 
qualified. If, unfortunately, some pilots experience IP but it is not addressed, it has the possibility to play a role in decision-making, which eventually becomes a safety concern. This is why more research in the aviation industry is crucial.

Potential risks in aviation. Aviation is analogous to medicine as errors by the individual may lead to fatality of other people. Considering that IP is ubiquitous among medical practitioners, there is a chance that it may be prevalent in the aviation industry as well. In this case, according to Hawley (2019), pilots who suffer from IP may (a) make efforts to reach overall expectations, (b) have depression, anxiety, or high levels of self-consciousness, or (c) make some abandonments. While there may be the inclination to state that IP will cause pilots in training to study harder and prepare more, the onset of anxiety and depression cannot be overstated as causes for concern. The importance of researching the prevalence of this phenomenon could be found in the better understanding of training pilot mindset and can be analyzed further to improve aviation safety. While some previous accidents could be used as potential examples of the dangers of IP in aviation, it has not yet been discovered to be a contributing factor for accidents. This is likely though because the concept of IP has not been introduced to aviation and is not a salient topic of research within the industry.

\section{Potential Factors Related to Imposter Phenomenon}

Personality. Although there are numerous personality models, one of the ways that researchers measure subjects' personalities is using the five-factor personality inventory (Digman, 1990). It is typically referred to as the Big Five or Five-Factor Model (De Fruyt, McCrae, Szirmák, \& Nagy, 2004). Previous research validates the use of this well-known model which includes factors of (a) extraversion, (b) agreeableness, (c) conscientiousness, (d) neuroticism, and (e) openness (Digman, 1990). These are the factors that were used to measure 
pilots' personalities in the current study. The measures of these five factors have been demonstrated to be appropriate to measure all individuals regardless of culture (Schmitt, Allik, McCrae, \& Benet-Martinez, 2007).

The reason for the inclusion of personality in the study was because these five factors may affect pilots' extent of IP. For example, pilots with higher levels of conscientiousness may be self-disciplined and lead to perfectionism, which can be an outcome of IP that Sherman (2013) asserted. Additionally, neuroticism can lead to anxiety and self-consciousness of successful pilots, making them experience IP (Kolligian \& Sternberg, 1991; Thompson, 2008). Therefore, these are elements of interest in the current research as potential predictors of IP.

Self-efficacy. Bandura (1982) defined the term of self-efficacy as the extent to which a person believes they can act or deal with expected situations well. The expectation of an individual's self-efficacy can influence (a) whether the person conducts coping behaviors, (b) how much effort this person wants to make, and (c) how long can the person persist when he/she encounters difficulty (Bandura, 1977). These outcomes can potentially determine if a person experiences IP. Within the scope of the current study, a pilot with low levels of self-efficacy has propensities to doubt future flight performance, which is an IA that was identified by Hawley (2019). Consequently, the pilot may experience a fear of being unmasked as an imposter and feel anxious or depressed.

Self-handicapping. The concept of self-handicapping was initially published by Berglas and Jones (1978). It mainly refers to the process when an individual adversely alters the environment, so that the potential failure can be attributed to the negative environment, to protect the image of competency (Berglas \& Jones, 1978). Berglas and Jones (1978) concluded that when male individuals attributed their recent successes to luck, they tended to take drugs. This in 
turn impaired their performance, and thus were able to blame the subsequent failures on drug use rather than on their incompetency. This behavior is related to IP, as victims of which doubt their skills, and do not want their conceived real capacity to be discovered. In this case, it is conceivable that a person who tends to self-handicap may exhibit traits of IP. In a previous related study, Cowman and Ferrari (2002) asserted that IP could be accounted for by selfhandicapping. Therefore, it is imperative to consider self-handicapping in the current study.

\section{Current Study}

From the analysis of previous literature, we have seen the effects, oftentimes negative, of the presence of an Imposter Phenomenon in an individual. The review of previous literature shows an extensive look at this phenomenon in several fields, but there appears to be a gap in the existing literature in relation to the aviation industry — specifically, the aviation training setting and student pilots. The purpose of this study is to address this specific gap in the literature with regards to the prevalence of and factors that impact the degree of collegiate flight students' Imposter Phenomenon.

\section{Operational Definitions}

To determine the factors that influence the degree of IP experienced by a collegiate pilot, 12 predictors were tested, namely, age, gender, ethnicity, education level, income, total flight hours, type of flight school training, pilot certification level, personality, measure of selfefficacy, measure of self-handicapping, and perceived organizational support of the pilot. Age, Income, and Total Flight Hours are continuous variables measured in years, U.S. dollars, and hours respectively. Gender, Ethnicity and Education Level are categorically defined as Male, Female, or Other; Caucasian (white, non-Hispanic), African descent, Asian descent (includes India), Latino/Hispanic descent, or Other; and High School Diploma, Associate's degree, 4-year 
Bachelor's degree, Master's degree, or Doctorate, respectively. Type of Flight School Training and Pilot Certification Level are also categorically defined as Part 141, or Part 61; and Student Pilot License, Private Pilot License, Commercial Pilot License, Air Transport Pilot License, or Other, respectively.

Personality, Self-Efficacy, Self-Handicapping, Perceived Organizational Support and Imposter Phenomenon are defined as a participant's scores on the Mini IPIP (International Personality Item Pool) Scale (Goldberg et al., 2006); Self-Efficacy Scale (Chen, Gully, \& Eden, 2001); Self-Handicapping Scale (Strube, 1986); Survey of Perceived Organizational Support (SPOS) (Eisenberger, Huntington, Hutchison, \& Sowa, 1986); and Imposter Phenomenon Scale (Clance, 1985).

\section{Hypothesis}

The hypothesis for the current study was as follows:

$\mathrm{H}_{1}$ : Age, gender, ethnicity, education level, income, total flight hours, type of flight school training, pilot certification level, personality, measure of self-efficacy, measure of self-handicapping, and perceived organizational support of the pilot are significant predictors of collegiate pilots' Imposter Phenomenon when controlling for each other.

\section{Methods}

\section{Participants}

This research aims to study the prevalence of Imposter Phenomenon (IP) within collegiate flight students. With this in mind, the target population remains collegiate flight students within the United States. Due to limited access, the accessible population for this study was represented by flight students at two southeastern universities in the U.S. that had collegiate flight training programs. Convenience samples of 113 and 128 flight students were collected 
from each university, respectively. Participants were recruited from collegiate ground school courses and through the university flight training department. Data points with missing data were excluded from the analyses, leaving a usable sample of 177 ( 21 women) data points. The mean age was $20.99(S D=3.26)$ years old. To create and validate the prediction model, two independent data sets are needed. Therefore, the data points were randomly spilt with cases being assigned to either the primary or secondary stages with each stage receiving the same proportion of participants from both universities. The primary stage had 89 participants with the secondary stage having the remaining 88 participants. These methodologies and designs have been utilized by previous research in this field and show the merit of the procedures (Kohavi, 1995; Mehta, Rice, Deaton, \& Winter, 2019; Mehta et al., 2020; Rice, Winter, Mehta, \& Ragbir, 2019).

\section{Materials and Stimuli}

Recruited participants were first provided with information about the study and were only presented the questionnaire once consent to participate was received. The participants were informed that the data collection process was anonymous and that their responses would remain confidential. The questionnaire first confirmed that participants were at least 18 years of age for ethical reasons. Participants who were not 18 were asked to stop and return the unfilled questionnaire. Participants continuing were asked demographic questions related to age, gender, ethnicity, income, education level, flight hours, type of flight school training, and their certificate level. Participants were then asked to complete certain validated scales for Personality, SelfEfficacy, and Self-Handicapping, Perceived Organizational Support, as well as the Clance IP Scale. A copy of the study questionnaire can be found in the Appendix. Following the collection of the questionnaires, the participants were debriefed and dismissed. There was no compensation for participating in the study. 


\section{Measures}

Harvey and Katz developed the Harvey Impostor Phenomenon Scale (HIPS) in 1985; however, the HIPS has certain issues with reliability (Kolligian \& Sternberg, 1991). Clance Impostor Phenomenon Scale (CIPS) (Clance, 1985), however, has been evaluated by Hawley (2019) as a standard IP measurement tool. Therefore, in this study, the CIPS was employed to identify participants' IP. The scale contains 20 items with each item scoring between 1 and 5, so the total score varies from 20 to 100 . Scores under 40 indicate the person experiences few IP traits; 41-60 indicate moderate IP traits; and 61-80 indicate frequent IP traits. Scores above 80 indicate IP traits with high frequency and intensity (Clance, 1985).

\section{Design}

A correlational design was used to conduct this study, with a backwards stepwise regression as the primary data analysis statistical procedure during the primary stage. The primary stage was to develop the regression equation of the model. The secondary stage involved the use of an independent samples $t$-test, a Pearson correlation, and a Cross-validated $R^{2}$ test to test for model fit. To create a prediction model, 12 factors were tested as the independent variables, namely, age, gender, ethnicity, education level, income, total flight hours, type of flight school training, pilot certification level, personality, measure of self-efficacy, measure of self-handicapping, and perceived organizational support. Participants' level of Imposter Phenomenon was the dependent variable, which was measured using the 20-question validated Clance (1985) Imposter Phenomenon scale.

\section{Results}

To create a prediction model of IP in collegiate pilots, a two-stage approach was taken, with the primary stage used to create the regression equation, and the secondary stage used as a 
validation tool to show model fit. As stated in the previous section, 12 predictors were tested for the influence on a collegiate pilot's IP. These predictors were age, gender, ethnicity, education level, income, total flight hours, type of flight school training, pilot certification level, personality, measure of self-efficacy, measure of self-handicapping, and perceived organizational support.

\section{Descriptive Statistics}

While the main purpose of this study is to develop a prediction model of IP within collegiate pilots, the IP scores, which are used as the dependent variable for the regression analysis, provide an interesting insight. The mean score of participant IP was $56.68(S D=13.05)$. The scores for the scale are broken down into the following thresholds. Scores under 40 imply that participants experience few imposter feelings. Scores from 41-60, 61-80, and 81-100 imply that participants have moderate, frequent, and intense imposter feelings, respectively. The average scores from this sample show that, on average, collegiate pilots have moderate feelings of IP. When extrapolating the findings of the sample to the larger population there is the potential to see some pilots experiencing frequent IP feelings. This, once again, re-iterates the need for this research, and for the importance of addressing these issues. A summary of the descriptive statistics is included in Table 1. 
Table 1

Summary of Descriptive Statistics

\begin{tabular}{|c|c|c|c|c|}
\hline & & $\mathbf{N}$ & $\mathbf{M}$ & SD \\
\hline Age & & 177 & 20.99 & 3.26 \\
\hline \multirow[t]{3}{*}{ Gender } & Male & $156(88 \%)$ & & \\
\hline & Female & $21(12 \%)$ & & \\
\hline & Other & 0 & & \\
\hline \multirow[t]{5}{*}{ Ethnicity } & Caucasian & $104(58 \%)$ & & \\
\hline & African & $16(9 \%)$ & & \\
\hline & Asian & $17(10 \%)$ & & \\
\hline & Hispanic & $19(11 \%)$ & & \\
\hline & Other & $21(12 \%)$ & & \\
\hline Income & & 177 & 9924.05 & 15507.37 \\
\hline \multirow[t]{5}{*}{ Education level } & HS Diploma & $144(81 \%)$ & & \\
\hline & Associate's & $24(14 \%)$ & & \\
\hline & Bachelor's & $6(3 \%)$ & & \\
\hline & Master's & $3(2 \%)$ & & \\
\hline & Doctorate & 0 & & \\
\hline Flight Hours & & 177 & 141.17 & 161.44 \\
\hline \multirow[t]{2}{*}{ Flight School } & Part 61 & $31(18 \%)$ & & \\
\hline & Part 141 & $146(82 \%)$ & & \\
\hline \multirow[t]{5}{*}{ Pilot Certificate Level } & Student Pilot & $57(32 \%)$ & & \\
\hline & Private Pilot & $95(54 \%)$ & & \\
\hline & Commercial Pilot & $22(12 \%)$ & & \\
\hline & Air Transport Pilot & 0 & & \\
\hline & Other & $3(2 \%)$ & & \\
\hline Personality & & 177 & 67.14 & 7.73 \\
\hline Self-Efficacy & & 177 & 4.33 & 0.49 \\
\hline Self-Handicapping & & 177 & 30.01 & 7.54 \\
\hline Perceived Organizational Support & & 177 & 31.76 & 9.75 \\
\hline Imposter Phenomenon & & 177 & 56.68 & 13.05 \\
\hline
\end{tabular}




\section{Primary Stage}

In this stage, 89 participants were utilized to determine which of the 12 predictors had a significant influence on collegiate pilots' IP. To determine the significant factors, a background stepwise regression was performed on the data set. Of the factors tested, four were found to be significant predictors of collegiate pilot's IP. These were measures of self-handicapping, measures of self-efficacy, income, and the type of flight school. Using this analysis, a regression equation was created:

$$
\mathrm{Y}=65.853+.726 \mathrm{X}_{1}-5.991 \mathrm{X}_{2}-.000147 \mathrm{X}_{3}-6.111 \mathrm{X}_{4}
$$

In the equation, Y represents the participant's IP score on the Clance (1985) IP scale, and $\mathrm{X}_{1}-$ $\mathrm{X}_{4}$ represent measures of self-handicapping, measures of self-efficacy, income, and the type of flight school, respectively. The beta coefficients, std. error, and significance values for each variable are displayed in Table 2.

Table 2

Beta Coefficients, Standard Error, $t$-value, and Sig. of the Primary Stage

\begin{tabular}{ccccc}
\hline & Beta Coef. & Std. Error & t-value & Sig. \\
\hline $\begin{array}{c}\text { Constant } \\
\text { Measure of Self- }\end{array}$ & 65.853 & 13.398 & 4.915 & $<.001$ \\
$\begin{array}{c}\text { Handicapping } \\
\text { Measure of Self-Efficacy }\end{array}$ & 0.726 & 0.154 & 4.706 & $<.001$ \\
Income & -5.991 & 2.493 & -2.403 & .018 \\
Type of Flight School & -.000147 & .000077 & -1.920 & .05 \\
\hline
\end{tabular}

The statistical calculations showed an overall $R^{2}=.406$ (adjusted $\left.R^{2}=.377\right)$. These findings suggest that approximately $40.6 \%$ of the variance in collegiate pilot IP can be attributed to a student's measure of self-handicapping, measure of self-efficacy, income, and the type of 
flight school. The data analysis revealed a statistically significant model with $F(4,84)=14.329$, $p<.001$

These results imply that a collegiate pilot's IP score will increase by .726 points for every 1-point increase in their self-handicapping score, while holding all other variables in the overall model constant. The coefficient was significant, $t(84)=4.706, p<.0001$. Collegiate pilot's IP score will decrease by 5.991 points for every 1-point increase in their self-efficacy score, while holding all other variables in the overall model constant. The coefficient was significant, $t(84)=$ $-2.403, p=.018$. Collegiate pilot's IP score will decrease by .147 points for every 1,000 dollars increase in their income, while holding all other variables in the overall model constant. The coefficient was significant, $t(84)=-1.920, p=.05$. Collegiate pilots who conduct their flight training under Part 141 on average, have IP scores 6.111 points lower than those who conduct their flight training under Part 61 when holding all other variables in the overall model constant. The coefficient was significant, $t(84)=-2.111, p=.037$.

\section{Secondary Stage}

The purpose of the secondary stage is to provide validation to the model and test the equation created in the primary stage with an independent sample. The equation from the primary stage was applied to the data of the secondary stage to obtain predicted scores of IP. These predicted scores were compared to the actual scores from the secondary stage to test for model fit. Model fit was tested in three different manners, used correlation, $t$-test, and crossvalidated $R^{2}$. These validation measures themselves have been utilized and validated by previous research studies (Mehta et al., 2019; Mehta et al., 2020; Rice et al., 2019).

The first test of model fit was a correlation analysis of the predicted scores of IP with the actual IP scores of the second stage, as explained earlier. The correlation analysis shows the 
degree of similarity between the actual and predicted scores. The findings of correlation analysis demonstrated a positive correlation between the actual and predicted scores, with $r(86)=.498$, $p<.0001$. Since the results show a statistically significant correlation, it lends itself to supporting the validity of the model.

The second test of model fit was an independent samples $t$-test. The actual and predicted scores used above were compared against each other to determine if they are statistically significantly different. Statistical insignificance here shows that there is no significant difference between the actual and predicted scores. The findings of the $t$-test show a statistically insignificant difference between the two scores, where $t(174)=-1.831, p=.069$. This once again lends strength to the validity of the model as the predicted scores are not statistically different from the predicted scores.

The $t$-test and correlation test are used to establish model-fit. The regression equation that was created was used on the secondary data set to create predicted scores of IP. The $t$-test was used to show that there was a statistically significant difference between the actual scores from the second data set and the predicted scores. The correlation test showed there was a statistically significant correlation between the actual scores from the second data set and the predicted scores. By showing through the $t$-test and correlation test that the two scores are not statistically significantly different, and are statistically significantly correlated, the authors can show model fit.

Lastly, a cross-validation analysis was run to further support the validity of the model using model fit. A cross-validated $R^{2}$ displays the degree to applicability of a model to new samples from the overall population. The findings of this analysis revealed a cross-validated $R^{2}$ of .350 . This shows that if the model were to be applied to other independent samples of the 
population, it would account for $35 \%$ of the variance in IP scores of those participants. The degree of closeness of the cross-validated $R^{2}$ and the original $R^{2}$ from the primary stage is the final show of support for the validity of the model.

\section{Discussion}

Twelve potential predictors were included in the model, and the data indicates four variables significantly predict IP. Using an independent sample of participants, model fit statistics assessed the predictive capabilities of the regression model, and all three measures supported strong model fit. Thus, the data indicates a strongly predictive statistical model was produced.

Self-handicapping was found to be the greatest contributor to the model, and it was also the only predictor to demonstrate a positive relationship with imposter syndrome, indicating that as a person's self-handicapping increases, so does their sense of being an imposter. The finding from this study is in line with earlier work by Cowman and Ferrari (2002) that also found that self-handicapping was related to IP. If flight students are having feelings of being an imposter, the attitude and environment that they create around them could be one of protectionism to try and defend against the negative feelings of being perceived as an imposter (Bothello \& Roulet, 2019; Clance \& Imes, 1978; Hawley, 2019; Kolligian \& Sternberg, 1991; Nimmo, 2019; Sakulku \& Alexander, 2011). An example scenario would be one where a flight student that is fearful of failing a flight checkride, or being negatively reviewed by their flight instructor may purposely perform pre-flight tasks incorrectly in order to postpone or cancel the flight lesson. This can clearly create an unsafe environment and is a cause for concern. The rationale suggests issues related to poor self-esteem, self-doubt, and negative feelings or attitudes toward the training process as driving factors. 
This finding is of particular importance to the current study as the behavior(s) related to self-handicapping may provide insights into the possibility of the existence of IP. Knowing the relationship between these two variables, individuals who interact with flights students, such as flight instructors, may be able to identify the behaviours related to self-handicapping, and therefore, be able to intervene to try and counter effects that could be related to IP. Flight instructors are given basic training on hazardous attitudes, and providing them with information related to the relationship between self-handicapping and Imposter Phenomenon may help to alleviate the effects as students complete their training.

Self-efficacy was found to have a significant and inverse relationship to IP, meaning that as a flight student's self-efficacy increases, their imposter phenomenon decreases. As this confidence increases, it is likely that feelings of being an imposter would diminish. However, in scenarios where flight students may not properly assess their skills or they feel they were not responsible for the successful outcome, such as when practicing how to handle emergency scenarios, this could lead to a decrease in feelings of self-efficacy (Bandura, 1977). As feelings of self-efficacy decrease, feelings related to IP may increase. The inverse relationship between these two variables provides some very meaningful aspects as it relates to flight training, particularly with post-flight briefings. Post-flight briefings can work to establish accurate perspectives of student performance, and thus hopefully result in validating the feelings of selfefficacy within the student. As the student's performance and assessment are validated, it is possible that their self-efficacy will increase throughout their training program, thus reducing the potential of feeling like an imposter.

An inverse relationship was found to exist between income and IP. This finding may be related to the evaluation of income as a form of success or validation. As an individual's salary 
increases, this may be an affirmation of their performance or a signal that they do, in fact, belong in the selected setting. Additionally, there is the inference of salaries increasing with increased experience. The driving force behind the decrease in IP may be attributed to increase in experience as well. Within the aviation industry and specifically for pilots, salaries are contractually negotiated and related to time in service and years of experience. As a pilot's salary increases, so may their assessment of their accomplishments, skills, and qualifications, which would likely result in a decrease in feelings of being an imposter. In the collegiate setting, with confounding variables playing a role in student income, this variable may have less of an impact in different samples and populations.

The last significant predictor of IP found in the current study is the type of flight school where training was completed. In aviation training, there are two main regulatory approaches to complete pilot training, 14 CFR Part 141, and 14 CFR Part 61. 14 CFR Part 141 are the regulatory approaches typically obtained by formal flight training schools, such as those at university flight programs or specialized programs, while training conducted under 14 CFR Part 61 tends to be more commonly associated with smaller flight schools. Pilots who completed training at the 14 CFR Part 141 schools were found to be less likely to have IP than those pilots who completed training at 14 CFR Part 61 programs.

This finding may be related to the more structured and formal approach that is often associated with 14 CFR Part 141 programs. It is also interesting to note that both university flight programs where students participated in the current study conduct training under 14 CFR Part 141. However, if students completed flight training before arriving to the university environment, it is more likely that they completed training under 14 CFR Part 61. As a result, participants in the structured format of 14 CFR Part 141 training may have stronger feelings of 
self-efficacy, which may be one explanation for the decreases in imposter feelings. While this is one plausible explanation, it must be stated, that there may be other confounding variables at play that could be influencing this factor. This is addressed in the limitations section as well.

\section{Practical Applications and Future Research}

The current study provides insight regarding pilots' Imposter Phenomenon in aviation. The relationship between IP and significant predictors, including self-handicapping, selfefficacy, income, and flight school type, can contribute to the aviation industry from the perspectives of student pilot instruction, and even student pilot mental health evaluation. As mentioned earlier, knowledge of the relationships between these factors can allow flight instructors to identify, intervene, and counteract the negative effects of these feelings. This study sheds light on the importance of focusing on IP in aviation, and especially aviation training, as a pilot's significant feeling of IP can lead to negative outcomes. This study helps the aviation training industry better understand pilots in training and can be used as a building block for making adjustments to training procedures.

The extension of the research on this topic is crucial to the understanding of potential causes and circumstances of pilots' IP. Other possible predictors (e.g., complacency, locus of control, check ride performance) can be tested in future studies. Future research may also seek to replicate this study using different populations, namely flight students outside of collegiate settings. Lastly, it is recommended that future research replicate the current study with commercial pilots to assess the ecological generalizability.

\section{Limitations}

Although measures were taken to control for as many variables as possible, there were still some limitations to the current study. The current study involved several different scales 
designed to measure personal aspects, such as self-efficacy, self-handicapping, and perceived organizational support. These scales were selected for inclusion because prior research has indicated that they may have an impact on participants' experiencing Imposter Phenomenon. However, the researchers acknowledge that there are different versions of these scales; and therefore, each scale version was compared to assess its overall validity and reliability. Thus, the researchers believe they have chosen the most appropriate scale version for this study.

Limitations also exist with the convenience sampling technique of using accessible populations within university flight training programs. This does have an impact on generalizability, but nevertheless, it provides for valuable insights into the mindset of collegiate flight students. Along the same lines, this study only researched collegiate flight students within the United States, and therefore, the findings may not be generalizable to flight training programs the world over.

Lastly, a thorough literature review helped the researchers decide which potential predictors to include; however, this list is not exhaustive. Additionally, as mentioned in the discussion, there may be confounding variables that influence the findings. Efforts were taken to account for these to the best practical extent, but with any research there are certain limitations that cannot be fully controlled. Future research should continue to explore this phenomenon with additional variables that may provide further insight into pilots' feelings of Imposter Phenomenon.

\section{Conclusion}

The purpose of the current study was to build a predictive model of IP in student pilots. This was accomplished by collecting data from 241 collegiate student pilots. A regression equation was developed during the first data collection and tested for model fit in the second data 
collection. Self-handicapping, measures of self-efficacy, income, and the type of flight school were all significant predictors and accounted for approximately $40 \%$ of the variance in the data. Model fit was strong, indicating that the regression equation can be used to predict future datasets. These data reveal that IP is prevalent in student pilots and should be addressed by flight schools when assessing potential future student pilot success. 


\section{References}

Bandura, A. (1977). Self-efficacy: Toward a unifying theory of behavioral change. Psychological Review, 84(2), 191-215. https://doi.org/10.1037//0033-295X.84.2.191

Bandura, A. (1982). Self-efficacy mechanism in human agency. American Psychologist, 37(2), 122-147. https://doi.org/10.1037/0003-066X.37.2.122

Berglas, S., \& Jones, E. E. (1978). Drug choice as a self-handicapping strategy in response to noncontigent success. Journal of Personality and Social Psychology, 36(4), 405-417. https://doi.org/10.1037/0022-3514.36.4.405

Bothello, J., \& Roulet, T. J. (2019). The imposter syndrome, or the mis-representation of self in academic life. Journal of Management Studies, 56(4), 854-861. https://doi.org/10.1111/joms.12344

Brauer, K., \& Proyer, R. T. (2017). Are impostors playful? Testing the association of adult playfulness with the impostor phenomenon. Personality and Individual Differences, 116, 57-62. https://doi.org/10.1016/j.paid.2017.04.029

Bravata, D. M., Watts, S. A., Keefer, A. L., Madhusudhan, D. K., Taylor, K. T., Clark, D. M., . . . Hagg, H. K. (2019). Prevalence, predictors, and treatment of impostor syndrome: A systematic review. Journal of General Internal Medicine, 35, 1252-1275. https://doi.org/10.1007/s11606-019-05364-1

Caselman, T. D., Self, P. A., \& Self, A. L. (2006). Adolescent attributes contributing to the imposter phenomenon. Journal of Adolescence, 29(3), 395-405. https://doi.org/10.1016/j.adolescence.2005.07.003 
Castro, D. M., Jones, R. A., \& Mirsalimi, H. (2004). Parentification and the impostor phenomenon: An empirical investigation. The American Journal of Family Therapy, 32(3), 205-216. https://doi.org/10.1080/01926180490425676

Chayer, M.-H., \& Bouffard, T. (2010). Relations between impostor feelings and upward and downward identification and contrast among 10- to 12-year-old students. European Journal of Psychology of Education, 25(1), 125-140. https://doi.org/10.1007/s10212-0090004-y

Chen, G., Gully, S. M., \& Eden, D. (2001). Validation of a new general self-efficacy scale. Organizational Research Methods, 4(1), 62-83. https://doi.org/10.1177/109442810141004

Clance, P. R. (1985). The Impostor Phenomenon: When Success Makes You Feel Like A Fake (pp. 20-22). Toronto, Canada: Bantam Books. https://doi.org/10.1037/t11274-000

Clance, P. R., \& Imes, S. A. (1978). The imposter phenomenon in high achieving women: Dynamics and therapeutic intervention. Psychotherapy: Theory, Research and Practice, 15(3), 241-247. https://doi.org/10.1037/h0086006

Cowman, S. E., \& Ferrari, J. R. (2002). "Am I for real?" Predicting impostor tendencies from self-handicapping and affective components. Social Behavior and Personality: An International Journal, 30(2), 119-125. https://doi.org/10.2224/sbp.2002.30.2.119

Data USA. (2018). Aircraft pilots \& flight engineers. Retrieved from https://datausa.io/profile/soc/aircraft-pilots-flight-engineers 
De Fruyt, F., McCrae, R. R., Szirmák, Z., \& Nagy, J. (2004). The five-factor personality inventory as a measure of the five-factor model: Belgian, American, and Hungarian comparisons with the NEO-PI-R. Assessment, 11(3), 207-215. https://doi.org/10.1177/1073191104265800

Digman, J. M. (1990). Personality structure: Emergence of the five-factor model. Annual Review of Psychology, 41(1), 417-440. https://doi.org/10.1146/annurev.ps.41.020190.002221

Eisenberger, R., Huntington, R., Hutchison, S., \& Sowa, D. (1986). Perceived organizational support. Journal of Applied Psychology, 71(3), 500-507. https://doi.org/10.1037/00219010.71 .3 .500

Federal Aviation Administration (FAA). (2019). U.S. Civil Airmen Statistics. Retrieved from https://www.faa.gov/data_research/aviation_data_statistics/civil_airmen_statistics/media/ 2018-civil-airmen-stats.xlsx

Goldberg, L. R., Johnson, J. A., Eber, H. W., Hogan, R., Ashton, M. C., Cloninger, C. R., \& Gough, H. G. (2006). The international personality item pool and the future of publicdomain personality measures. Journal of Research in Personality, 40(1), 84-96. https://doi.org/10.1016/j.jrp.2005.08.007

Goyer, M. (2020). Five decades of American female pilots statistics. How did we do? Institute for Women of Aviation Worldwide. Retrieved from https://womenofaviationweek.org/five-decades-of-women-pilots-in-the-united-stateshow-did-we-do/

Hawley, K. (2019). I-What is impostor syndrome? Aristotelian Society Supplementary Volume, 93(1), 203-226. https://doi.org/10.1093/arisup/akz003 
Kohavi, R. (1995, August). A study of cross-validation and bootstrap for accuracy estimation and model selection. International Joint Conference on Artificial Intelligence, 14(2), $1137-1145$.

Kolligian, J., Jr., \& Sternberg, R. J. (1991). Perceived fraudulence in young adults: Is there an 'imposter syndrome'? Journal of Personality Assessment, 56(2), 308-326. https://doi.org/10.1207/s15327752jpa5602_10

Mehta, R., Rice, S., Deaton, J., \& Winter, S. R. (2019). Creating a prediction model of passenger preference between low cost and legacy airlines. Transportation Research Interdisciplinary Perspectives, 3. https://doi.org/10.1016/j.trip.2019.100075

Mehta, R., Rice, S., Winter, S. R., Anania, E. C., Baugh, B. S., \& Milner, M. N. (2020).

Determining the predictors for ease of sleep while on aircraft: Regression and qualitative analyses. Journal of Air Transport Management, 83. https://doi.org/10.1016/j.jairtraman.2019.101756

Mullangi, S., \& Jagsi, R. (2019). Imposter syndrome: Treat the cause, not the symptom. JAMA, 322(5), 403-404. https://doi.org/10.1001/jama.2019.9788

Nimmo, S. (2019). Imposter syndrome. Occupational Medicine, 69(5), 318. https://doi.org/10.1093/occmed/kqz052

Rice, S., Winter, S. R., Mehta, R., \& Ragbir, N. K. (2019). What factors predict the type of person who is willing to fly in an autonomous commercial airplane? Journal of Air Transport Management, 75, 131-138. https://doi.org/10.1016/j.jairtraman.2018.12.008 
Sakulku, J., \& Alexander, J. (2011). The impostor phenomenon. International Journal of Behavioral Science, 6(1), 73-92. Retrieved from https://www.sciencetheearth.com/uploads/2/4/6/5/24658156/2011_sakulku_the_impostor _phenomenon.pdf

Schmitt, D. P., Allik, J., McCrae, R. R., \& Benet-Martinez, V. (2007). The geographic distribution of big five personality traits: Patterns and profiles of human self-description across 56 nations. Journal of Cross-Cultural Psychology, 38(2), 173-212. https://doi.org/10.1177/0022022106297299

Sherman, R. O. (2013). Imposter syndrome: When you feel like you're faking it. American Nurse Today, 8(5), 57-58. Retrieved from https://go-galecom.portal.lib.fit.edu/ps/i.do?p=AONE\&u=melb26933\&id=GALE\%7CA335410366\&v= 2.1\&it=r\&sid=summon

Strube, M. J. (1986). An analysis of the self-handicapping scale. Basic and Applied Social Psychology, 7(3), 211-224. https://doi.org/10.1207/s15324834basp0703_4

Thompson, E. R. (2008). Development and validation of an international English big-five minimarkers. Personality and Individual Differences, 45(6), 542-548. https://doi.org/10.1016/j.paid.2008.06.013

Vail, G. J., \& Ekman, L. G. (1986). Pilot-error accidents: Male vs female. Applied Ergonomics, 17(4), 297-303. https://doi.org/10.1016/0003-6870(86)90133-X

Villwock, J. A., Sobin, L. B., Koester, L. A., \& Harris, T. M. (2016). Impostor syndrome and burnout among American medical students: A pilot study. International Journal of Medical Education, 7, 364-369. https://doi.org/10.5116/ijme.5801.eac4 


\section{Appendix - Study Questionnaire}

1. Are you at least 18 years old?
a. Yes
b. No

IF YOU ARE NOT 18 YEARS OF AGE, PLEASE STOP HERE, AND RETURN THE QUESTIONNAIRE TO THE RESEARCHER

Instructions: You will be asked some demographics questions. Following that, you will be asked some questions, along with several validated scales for Personality, Self-Efficacy, and Self-Handicapping, Perceived Organizational Support, as well as the Clance IP Scale. The data collection process is anonymous, and your responses will remain confidential.

2. Please state your age in the box provided below

3. Please state your gender below
a. Male
b. Female
c. Other:

4. Please state your ethnicity below
a. Caucasian (white, non-Hispanic)
b. African descent
c. Asian descent (Includes India)
d. Latino/Hispanic descent
e. Other: 
5. Please state your yearly income (US Dollars) in the box provided below

6. Please state your highest education level you have achieved below
a. High School Diploma
b. Associate's degree
c. 4-year Bachelor's degree
d. Master's degree
e. Doctorate

7. Please state your approximate total number of flight hours in the box provided below

8. Please state the type of flight school training that you received most of your licenses through
a. Part 141 Flight School
b. Part 61 Flight School

9. Please state the highest certificate/license that you have obtained
a. Student Pilot License
b. Private Pilot License
c. Commercial Pilot License
d. Air Transport Pilot License
e. Other: 


\section{Personality}

Describe yourself as you generally are now, not as you wish to be in the future. Describe yourself as you honestly see yourself, in relation to other people you know of the same sex as you are, and roughly your same age.

Indicate for each statement how accurate the description is of you. Place only one check per row.

\begin{tabular}{|c|c|c|c|c|c|}
\hline & $\begin{array}{c}\text { Very } \\
\text { Inaccurate }\end{array}$ & $\begin{array}{l}\text { Moderately } \\
\text { Inaccurate }\end{array}$ & $\begin{array}{c}\text { Neither } \\
\text { Accurate } \\
\text { nor } \\
\text { Inaccurate }\end{array}$ & $\begin{array}{c}\text { Moderately } \\
\text { Accurate }\end{array}$ & $\begin{array}{c}\text { Very } \\
\text { Accurate }\end{array}$ \\
\hline \multicolumn{6}{|l|}{ Seldom feel blue. } \\
\hline \multicolumn{6}{|l|}{ Am not interested in abstract ideas. } \\
\hline \multicolumn{6}{|l|}{ Am not really interested in others. } \\
\hline \multicolumn{6}{|l|}{ Don't talk a lot. } \\
\hline \multicolumn{6}{|c|}{ Have difficulty understanding abstract ideas. } \\
\hline \multicolumn{6}{|l|}{ Get upset easily. } \\
\hline \multicolumn{6}{|l|}{ Like order. } \\
\hline \multicolumn{6}{|l|}{ Have frequent mood swings. } \\
\hline \multicolumn{6}{|l|}{ Talk to a lot of different people at parties. } \\
\hline \multicolumn{6}{|l|}{ Am the life of the party. } \\
\hline \multicolumn{6}{|l|}{ Do not have a good imagination. } \\
\hline \multicolumn{6}{|l|}{ Make a mess of things. } \\
\hline \multicolumn{6}{|l|}{ Feel others' emotions. } \\
\hline \multicolumn{6}{|l|}{ Get chores done right away. } \\
\hline \multicolumn{6}{|l|}{ Am relaxed most of the time. } \\
\hline Sympathize with others' feelings. & & & & & \\
\hline
\end{tabular}




\section{M ehta et al.: W hat Type of Collegiate Pilot is Likely to Experience Imposter Ph}

\section{Self-Efficacy}

Self-efficacy refers to your overall belief in how well you can complete a task or perform an activity.

Indicate for each statement how accurate the description is of you. Place only one check per row.

\begin{tabular}{|c|c|c|c|c|c|}
\hline & $\begin{array}{l}\text { Strongly } \\
\text { Disagree }\end{array}$ & Disagree & $\begin{array}{c}\text { Neither } \\
\text { Disagree nor } \\
\text { Agree } \\
\end{array}$ & Agree & $\begin{array}{c}\text { Strongly } \\
\text { Agree }\end{array}$ \\
\hline \multicolumn{6}{|l|}{$\begin{array}{l}\text { I will be able to achieve most of the goals that I set for } \\
\text { myself. }\end{array}$} \\
\hline \multicolumn{6}{|l|}{$\begin{array}{l}\text { When facing difficult tasks, I am certain that I will } \\
\text { accomplish them. }\end{array}$} \\
\hline \multicolumn{6}{|l|}{$\begin{array}{c}\text { In general, I think that I can obtain outcomes that are } \\
\text { important to me. }\end{array}$} \\
\hline \multicolumn{6}{|l|}{$\begin{array}{l}\text { I believe I can succeed at most any endeavor to which I } \\
\text { set my mind. }\end{array}$} \\
\hline $\begin{array}{c}\text { I will be able to successfully overcome many } \\
\text { challenges. }\end{array}$ & & & & & \\
\hline
\end{tabular}

\section{Self-Handicapping}

Self-handicapping occurs when you purposefully avoid putting in effort to accomplish a task in order to avoid feeling disappointed if you fail at that task in the future.

Indicate for each statement how accurate the description is of you. Place only one check per row.

\begin{tabular}{|c|c|c|c|c|c|c|}
\hline & $\begin{array}{c}\text { Disagree } \\
\text { very much }\end{array}$ & $\begin{array}{c}\text { Disagree } \\
\text { pretty much }\end{array}$ & $\begin{array}{l}\text { Disagree a } \\
\text { little }\end{array}$ & Agree a little & $\begin{array}{l}\text { Agree } \\
\text { pretty } \\
\text { much }\end{array}$ & $\begin{array}{c}\text { Agree } \\
\text { very much }\end{array}$ \\
\hline \multicolumn{7}{|l|}{$\begin{array}{l}\text { I tend to make excuses when I do something } \\
\text { wrong. }\end{array}$} \\
\hline \multicolumn{7}{|l|}{ I tend to put things off until the last moment. } \\
\hline \multicolumn{7}{|l|}{$\begin{array}{l}\text { I suppose I feel "under the weather" more often } \\
\text { than most people. }\end{array}$} \\
\hline \multicolumn{7}{|l|}{ I always try do my best, no matter what. } \\
\hline \multicolumn{7}{|l|}{$\begin{array}{l}\text { I am easily distracted by noises or my own } \\
\text { daydreaming when I try to read. }\end{array}$} \\
\hline \multicolumn{7}{|l|}{$\begin{array}{l}\text { I try not to get too intensely involved in } \\
\text { competitive activities so it won't hurt too much if I } \\
\text { lose or do poorly. }\end{array}$} \\
\hline \multicolumn{7}{|l|}{ I would do a lot better if I tried harder. } \\
\hline \multicolumn{7}{|l|}{$\begin{array}{l}\text { I sometimes enjoy being mildly ill for a day or } \\
\text { two. }\end{array}$} \\
\hline \multicolumn{7}{|l|}{$\begin{array}{l}\text { I tend to rationalize when I don't live up to others' } \\
\text { expectations. }\end{array}$} \\
\hline $\begin{array}{l}\text { I overindulge in food and drink more often than I } \\
\text { should. }\end{array}$ & & & & & & \\
\hline
\end{tabular}


Perceived Organizational Support

Listed below are statements that represent possible opinions that you may have about working at your job.

Indicate for each statement how accurate the description is of you. Place only one check per row.

\begin{tabular}{|c|c|c|c|c|c|c|c|}
\hline & $\begin{array}{l}\text { Strongly } \\
\text { Disagree }\end{array}$ & $\begin{array}{l}\text { Moderately } \\
\text { Disagree }\end{array}$ & $\begin{array}{c}\text { Slightly } \\
\text { Disagree }\end{array}$ & $\begin{array}{c}\text { Neither } \\
\text { Disagree } \\
\text { nor Agree }\end{array}$ & $\begin{array}{c}\text { Slightly } \\
\text { Agree }\end{array}$ & $\begin{array}{l}\text { Moderately } \\
\text { Agree }\end{array}$ & $\begin{array}{l}\text { Strongly } \\
\text { Agree }\end{array}$ \\
\hline \multicolumn{8}{|l|}{$\begin{array}{l}\text { The organization values my } \\
\text { contribution to its well-being. }\end{array}$} \\
\hline \multicolumn{8}{|l|}{$\begin{array}{l}\text { The organization fails to appreciate } \\
\text { any extra effort from me. }\end{array}$} \\
\hline \multicolumn{8}{|l|}{$\begin{array}{l}\text { The organization would ignore any } \\
\text { complaint from me. }\end{array}$} \\
\hline \multicolumn{8}{|l|}{$\begin{array}{l}\text { The organization really cares about } \\
\text { my well- being. }\end{array}$} \\
\hline \multicolumn{8}{|l|}{$\begin{array}{l}\text { Even if I did the best job possible, the } \\
\text { organization would fail to notice. }\end{array}$} \\
\hline \multicolumn{8}{|l|}{$\begin{array}{l}\text { The organization cares about my } \\
\text { general satisfaction at work. }\end{array}$} \\
\hline \multicolumn{8}{|l|}{$\begin{array}{l}\text { The organization shows very little } \\
\text { concern for me. }\end{array}$} \\
\hline $\begin{array}{l}\text { The organization takes pride in my } \\
\text { accomplishments at work. }\end{array}$ & & & & & & & \\
\hline
\end{tabular}




\section{Clance IP Scale}

For each question, please check the number that best indicates how true the statement is of you. It is best to give the first response that enters your mind rather than dwelling on each statement and thinking about it over and over.

\begin{tabular}{|c|c|c|c|c|c|}
\hline & $\begin{array}{c}1- \\
\text { Not } \\
\text { true } \\
\text { at all } \\
\end{array}$ & $\begin{array}{c}2- \\
\text { Rarely }\end{array}$ & $\begin{array}{l}3- \\
\text { Sometimes }\end{array}$ & $\begin{array}{c}4- \\
\text { Often }\end{array}$ & $\begin{array}{c}5- \\
\text { Very } \\
\text { True }\end{array}$ \\
\hline \multicolumn{6}{|l|}{$\begin{array}{l}\text { I have often succeeded on a test or task even though I was afraid that I would not do well before } \\
\text { I undertook the task. }\end{array}$} \\
\hline \multicolumn{6}{|l|}{ I can give the impression that I'm more competent than I really am. } \\
\hline \multicolumn{6}{|l|}{ I avoid evaluations if possible and have a dread of others evaluating me. } \\
\hline \multicolumn{6}{|l|}{$\begin{array}{l}\text { When people praise me for something I've accomplished, I'm afraid I won't be able to live up } \\
\text { to their expectations of me in the future. }\end{array}$} \\
\hline \multicolumn{6}{|l|}{$\begin{array}{l}\text { I sometimes think I obtained my present position or gained my present success because I } \\
\text { happened to be in the right place at the right time or knew the right people. }\end{array}$} \\
\hline \multicolumn{6}{|l|}{ I'm afraid people important to me may find out that I'm not as capable as they think I am. } \\
\hline \multicolumn{6}{|l|}{$\begin{array}{c}\text { I tend to remember the incidents in which I have not done my best more than those times I have } \\
\text { done my best. }\end{array}$} \\
\hline \multicolumn{6}{|l|}{ I rarely do a project or task as well as I'd like to do it. } \\
\hline \multicolumn{6}{|l|}{$\begin{array}{c}\text { Sometimes I feel or believe that my success in my life or in my job has been the result of some } \\
\text { kind of error. }\end{array}$} \\
\hline \multicolumn{6}{|l|}{ It's hard for me to accept compliments or praise about my intelligence or accomplishments. } \\
\hline \multicolumn{6}{|l|}{ At times, I feel my success has been due to some kind of luck. } \\
\hline \multicolumn{6}{|l|}{$\begin{array}{l}\text { I'm disappointed at times in my present accomplishments and think I should have accomplished } \\
\text { much more. }\end{array}$} \\
\hline \multicolumn{6}{|l|}{ Sometimes I'm afraid others will discover how much knowledge or ability I really lack. } \\
\hline \multicolumn{6}{|l|}{$\begin{array}{l}\text { I'm often afraid that I may fail at a new assignment or undertaking even though I generally do } \\
\text { well at what I attempt. }\end{array}$} \\
\hline \multicolumn{6}{|l|}{$\begin{array}{l}\text { When I've succeeded at something and received recognition for my accomplishments, I have } \\
\text { doubts that I can keep repeating that success. }\end{array}$} \\
\hline \multicolumn{6}{|l|}{$\begin{array}{l}\text { If I receive a great deal of praise and recognition for something I've accomplished, I tend to } \\
\text { discount the importance of what I've done. }\end{array}$} \\
\hline \multicolumn{6}{|l|}{ I often compare my ability to those around me and think they may be more intelligent than I am. } \\
\hline \multicolumn{6}{|l|}{$\begin{array}{l}\text { I often worry about not succeeding with a project or examination, even though others around me } \\
\text { have considerable confidence that I will do well. }\end{array}$} \\
\hline \multicolumn{6}{|l|}{$\begin{array}{l}\text { If I'm going to receive a promotion or gain recognition of some kind, I hesitate to tell others } \\
\text { until it is an accomplished fact. }\end{array}$} \\
\hline $\begin{array}{c}\text { I feel bad and discouraged if I'm not "the best" or at least "very special" in situations that } \\
\text { involve achievement. }\end{array}$ & & & & & \\
\hline
\end{tabular}

